\title{
P4-246
}

[C3.3-4] Soil Management Strategy for Enhancing Crop Yields

\section{Zinc, Copper, Boron and Iron Requirement of Upland Rice Grown on a Brazilian Oxisol}

\author{
Nand Kumar Fageria and Adriano Stephan Nascente ${ }^{*}$
}

National Rice and Bean Research Center of EMBRAPA (Empresa Brasileira de Pesquisa Agropecuaria), Caixa Postal 179, Santo

\author{
Antonio de Goias, GO, CEP 75375-000, Brazil \\ adriano.nascente@embrapa.br
}

Deficiency of micronutrients increasing in field crops, including upland rice in recent years. The objective of this study was to determine requirement of zinc $(\mathrm{Zn})$, copper $(\mathrm{Cu})$ boron $(\mathrm{B})$ and iron $(\mathrm{Fe})$ for upland rice grown on a Brazilian Oxisol. The levels used were: $\mathrm{Zn}(0,10,20,40$, and $80 \mathrm{mg} \mathrm{kg-1)}, \mathrm{Cu}(0,5,10,20$ and $40 \mathrm{mg} \mathrm{kg-1}), \mathrm{B}(0,5,10,20$ and $40 \mathrm{mg} \mathrm{kg}-1)$ and Fe (0, 250, 500, 1000, and $2000 \mathrm{mg} \mathrm{kg-1).} \mathrm{Plant} \mathrm{height,} \mathrm{straw} \mathrm{yield,} \mathrm{grain} \mathrm{yield,} \mathrm{panicle} \mathrm{number} \mathrm{and} \mathrm{grain} \mathrm{harvest} \mathrm{index} \mathrm{(GHI)} \mathrm{were}$ significantly improved with the addition of these micronutrients. Root growth was also improved with the application of micronutrients, except with the addition of B. Maximum grain yield was obtained with the addition of $51 \mathrm{mg} \mathrm{Zn}, 24 \mathrm{mg} \mathrm{Cu}, 5 \mathrm{mg}$ B kg-1 and $283 \mathrm{mg} \mathrm{Fe} \mathrm{kg-1} \mathrm{soil.} \mathrm{Similarly,} \mathrm{maximum} \mathrm{straw} \mathrm{yield} \mathrm{was} \mathrm{obtained} \mathrm{with} \mathrm{the} \mathrm{addition} \mathrm{of} 38 \mathrm{mg} \mathrm{Zn,} 17 \mathrm{mg} \mathrm{Cu}, 6 \mathrm{mg} \mathrm{B}$ kg-1 and 1500 mg Fe kg-1 soil. Maximum plant height was obtained with the addition of 54 mg Zn, 10 mg B kg-1 and 1197 mg Fe kg-1 soil. Copper did not affect plant height significantly. Maximum panicle number was obtained with the addition of $22 \mathrm{mg} \mathrm{Cu}$ kg-1, 3 mg B kg-1 and 1100 mg Fe kg-1 soil. Zinc did not affect panicle number significantly. Maximum GHI was obtained with the addition of $61 \mathrm{mg} \mathrm{Zn} \mathrm{kg-1,} \mathrm{and} 8 \mathrm{mg} \mathrm{B} \mathrm{kg-1.} \mathrm{Zinc} \mathrm{was} \mathrm{having} \mathrm{linear} \mathrm{increase} \mathrm{in} \mathrm{GHI} \mathrm{in} \mathrm{the} \mathrm{range} \mathrm{of} 0$ to $80 \mathrm{mg} \mathrm{kg}-1$ and Fe was having negative relationship with GHI.

Keywords : grain harvest index, Oryza sativa, Oxisol, yield and yield components 